\title{
Chemical Composition of Kapok (Ceibapentandra) Seed and Physicochemical Properties of its Oil
}

\author{
${ }^{*}$ K.M. Anigo, ${ }^{2 B}$.M.D. Dauda, ${ }^{1}$ A.B. Sallau and ${ }^{1}$ I.E.Chindo \\ 1Department of Biochemistry, Ahmadu Bello University, Zaria \\ 2Department of Textile Science and Technology, Ahmadu Bello University, Zaria \\ [Corresponding Author, E-mail: mkanigo@yahoo.com; 留: +2348073197086]
}

\begin{abstract}
Determination of the chemical composition of Kapok (Ceibapentandra) seeds and physicochemical properties of its oil were carried out using standard methods. Mature dried fruits of Kapok from which seeds were obtained were collected from in and around Basawa village, Sabon Gari Local Government Area, Kaduna State. Results of proximate analysis show crude fat $(23.10 \%)$ and crude protein, $(36.70 \%)$ while calcium $(1212 \mathrm{mg} / \mathrm{kg})$ was most abundant among minerals analysed. Kapok seed oil had clear bright yellowish colour with offensive odour with iodine value, $(76.80 \mathrm{~g} \mathrm{l} / 100 \mathrm{~g}$ oil) and saponification value, $(179.77 \mathrm{mg} \mathrm{KOH} / \mathrm{g}$ oil). Lignin content of the kapok fiber was $5.54 \%$. We concluded that the kapok seeds, which are under-utilized and often discarded as an agrowaste in our environment, is rich in oil and protein therefore, has a reasonable economic potential which can be harnessed.
\end{abstract}

Keywords: Kapok, Ceibapentandra, physicochemical properties, oil, iodine value, saponification value

\section{INTRODUCTION}

Kapok [Ceibapentandra(L) Gaertn., Family Bombacaceae], the silk cotton tree, is native to the New World and Africa, found widespread in the tropics and in several plantations in Southeast Asia, and known for its white silky floss (Mojica et al., 2002; Chaiarrekij, 2011). There is strong ecological, botanical and cytological evidence that the trees' original distribution may have been in western and central Africa. It is the largest African forest tree and severally known among some Nigerian ethnic groups as Rimi (Hausa), Bamtami (Fulani), Arabaogungun (Yoruba) and Akpi (Igbo).

Kapok is a fast growing tree and becomes productive within 4-5 years. Yields increase for about 8 years and its economical lifespan is about 60 years. A tree under optimal conditions may yield 330-400 fruits per year, giving $15-18 \mathrm{~kg}$ fibre and about $30 \mathrm{~kg}$ seeds. A satisfactory fibre yield is about $450 \mathrm{~kg} / \mathrm{ha}$ and a very good yield is about $700 \mathrm{~kg} / \mathrm{ha}$ (Louppeet al., 2008). Kapok tree produces between 500 and 4,000 fruits at one time, with each fruit containing 200 seeds. Each kapok tree bears 1000 to 2000 pods annually (Narahari and AshaRajini, 2003). When these fruit burst open, silky fibers spread the many seeds all over the environs.

Kapok fiber is an agricultural product obtained from the fruits of the kapok tree (Tang et al., 2008; Qiuling and Lin, 2009). Kapok fibers are fluffy, light-weight, and too in elastic to be span. Kapok fibre is much appreciated for its low density and insulating properties that made it suitable for a large number of commercial applications, including pillows, upholstery, mattresses, soft toys clothes stuffing, thermal and acoustic insulation (Bates 2004; Orwaet al., 2009; Chairrekijet al., 2011). Kapok wood is a light, porous and resistant timber useful for plywood, packaging, carvings, and dugout canoes (Orwaet al., 2009). The seeds are also used as food/feed for humans and livestocks (Danso, 2001). Hassan et al., (2007) reported that Kapok seed is a very good source of edible oil and have the potential for use as raw material in paint industries. Kapok seed has the potential to be used as raw material for biodiesel (Putriet al., 2012).

Data on the nutritive value of locally available Kapok seeds in our environment is essential for an effective and efficient use of available resources, an effort towards reaping its economic benefits.

\section{MATERIALS AND METHODS \\ Seeds}

Mature dried fruits of Kapok (Ceibapentandra) were obtained from in and aroundBasawa village, SabonGari Local Government Area, Kaduna State. The seeds were separated from the fruits manually after cutting with a sharp steel knife from which healthy seeds were selected. The seeds were cleaned and oven-dried at $40^{\circ} \mathrm{C}$ for $24 \mathrm{~h}$ and were ground into uniform size, that passed through 80-mesh sieve which was then stored in clean dry plastic container until needed for analysis. 


\section{Chemical Analysis}

Samples and standard solutions were prepared according to the procedures of the AOAC (1990).The standard analytical procedures were adopted for determinations of moisture content, ash, crude protein and crude fat (AOAC, 1990). The amount of protein was calculated by multiplying $\%$ of nitrogen determined by the conversion factor 6.25 according to Kjeldhal method. Total carbohydrate was determined by difference.

Mineral element analysis:Concentration of minerals ( $\mathrm{Mg}, \mathrm{Fe}, \mathrm{Mn}, \mathrm{Ca}, \mathrm{Zn}$ and $\mathrm{Co}$ ) was determined after acid digestion using atomic absorption spectrophotometer (AOAC, 1990). Physicochemical properties of seed oil:The seed oil was extracted by soxhlet extraction method using petroleum ether (b.p. $40-60^{\circ} \mathrm{C}$ ) as refluxing solvent. At the completion of extraction process, the oil was recovered by distillation and stored at $4^{\circ} \mathrm{C}$ until required for use. Physicochemical properties (Iodine value and Saponification value) of the extracted kapok seed oil were determined in accordance with AOAC Official Methods (1990). Determination of lignin in the kapok fibre was done using method described by AOAC (1990).

\section{RESULTS AND DISCUSSION}

The weight obtained (Table 1) for fibre $(11.66 \mathrm{~g})$ was lower while that of seeds $(13.87 \mathrm{~g})$ was higher than $10 \mathrm{~g}$ and $17 \mathrm{~g}$ per fruit respectively reported by Salgado and Ciaramello (1990).

The rate of deterioration of food is directly dependent on its moisture content (Burris, 1980). The low moisture indicates the seeds are much less prone to microbial attack in the course of storage (Hassan et al., 2006). Crude fat $(23.10 \%)$ obtained in this study fell within values of $21-29 \%$ reported (Heuzé and Tran, 2011) but lower than reported values of $28.7 \%$ in Malaysian kapok seed (Berry, 1979) and 34\% in kapok seed obtained from Kurfi village of Kware Local Government Area, Sokoto State, Nigeria (Hassan et al., 2006). Considering the crude fat content $(23.10 \%)$ of the Kapok seed indicates that it is very promising for commercial benefits as reported by Hassan et al. (2006). Salgado and Ciaramello (1990) also reported that kapok seed oil showed good oil characteristics for cooking. Kapok seeds are rich in protein as indicated in this study with crude protein content (36.70\%) higher than 23-30\% reported by Heuzé and Tran, (2011). The observed variations in proximate parameters of the seeds might be attributed to the varying harvesting regime and origin of the fruit used. Mineral elements play important roles in the body like formation of healthy bones and teeth, hemoglobin, normal blood clotting, and nervous system functioning. This difference may be due to variations in climatic, environmental and agronomic practices which indicates higher yield of fibre with less seeds for the Kapok fruit obtained in this environment. Results of proximate analysis (Table 2) showed moisture content of Kapok seed obtained in this study (7.88\%) was lower than 10\% reported (Hassan et al., 2006).

Table 3 showed values obtained for some minerals analyzed, which were highly variable with lower values obtained for Mg $(234.58 \mathrm{mg} / \mathrm{kg})$, Fe $(124.5 \mathrm{mg} / \mathrm{kg}), \mathrm{Mn}$ $(25.27 \mathrm{mg} / \mathrm{kg}), \mathrm{Zn}(197.59 \mathrm{mg} / \mathrm{kg})$ and Co $(0.85 \mathrm{mg} / \mathrm{kg})$ when compared to $230.07,34.30,5.44,22.5$ and $6.5 \mathrm{mg} / 100 \mathrm{~g}$ respectively reported (Hassan et al., 2006). However, higher calcium content $(1212.38 \mathrm{mg} / \mathrm{kg}$ ) was recorded than $66.25 \mathrm{mg} / 100 \mathrm{~g}$ reported by Hassan et al., (2006). The mineral compositions of kapok seed obtained in this study can contribute to dietary requirement in order to meet recommended dietary allowance.

Table 1: Weight of Fruit, Seed and Fibre of Kapok

\begin{tabular}{lll}
\hline Parameter & Weight $(\mathbf{g})$ & \% fruit \\
\hline Pod & $34.64 \pm 2.20$ & 57.87 \\
Fibre & $11.66 \pm 0.54$ & 18.84 \\
Seeds & $13.87 \pm 0.40$ & 23.29 \\
Fruit & $59.55 \pm 2.88$ & 100.0 \\
\hline
\end{tabular}

Values are mean \pm SD of triplicate determinations

Table 2: Proximate Composition of Kapok Seed

\begin{tabular}{ll}
\hline Parameter & Concentration $(\mathbf{g} / \mathbf{1 0 0 g})$ \\
\hline Crude protein & $36.90 \pm 0.52$ \\
Crude fat & $23.10 \pm 0.37$ \\
Ash & $5.87 \pm 0.06$ \\
Moisture & $7.88 \pm 0.06$ \\
Total carbohydrate & $26.25 \pm 0.10$ \\
\hline
\end{tabular}

Table 3: Mineral element contents of Kapok seed

\begin{tabular}{ll}
\hline Mineral Element & Concentration $(\mathrm{mg} / \mathrm{kg})$ \\
\hline Magnesium $(\mathrm{Mg})$ & $234.58 \pm 0.04$ \\
Iron (Fe) & $124.52 \pm 0.05$ \\
Manganese $(\mathrm{Mn})$ & $25.27 \pm 0.05$ \\
Calcium $(\mathrm{Ca})$ & $1212.38 \pm 0.02$ \\
Zinc $(\mathrm{Zn})$ & $197.59 \pm 0.17$ \\
Cobalt $(\mathrm{Co})$ & $0.85 \pm 0.01$ \\
\hline
\end{tabular}


Physicochemical attributes of the seed oil are given in Table 4. Kapok seed oil obtained in this study had clear bright yellowish colour with offensive odour which agrees with thick yellowish colour and pungent odour as was reported earlier (Berry, 1979; Ravi Kiran et al., 2012). lodine value, which predicts the degree of unsaturation of oil, was $76.80 \mathrm{~g} \mathrm{l} / 100 \mathrm{~g}$ oil and Saponification value was $179.77 \mathrm{mg} \mathrm{KOH} / \mathrm{g}$ oil which are lower than $94.98 \mathrm{~g} \mathrm{l} / 100 \mathrm{~g}$ oil and $183.0 \mathrm{mg} \mathrm{KOH} / \mathrm{g}$ oil reported (Berry 1979) respectively in Malalysian kapok seed oil. The oils with higher iodine and saponification value are suitable for soft soap and cosmetics production as well as for edible applications (Akanniet al., 2005).

Table 4: Physicochemical Properties of Kapok Seeds Oil

\begin{tabular}{ll}
\hline Parameter & Characteristic \\
\hline Physical State & Slightly viscous \\
Colour & Brightly yellow \\
Odour & Slightly offensive \\
Saponfication Value $(\mathrm{mg} / \mathrm{g})$ & $179.77 \pm 2.07$ \\
lodine Value $(\mathrm{g} / 100 \mathrm{~g})$ & $76.80 \pm 0.50$ \\
\hline
\end{tabular}

Table 5: Lignin and Protein Content of Fibre of Seed of Kapok

\begin{tabular}{ll}
\hline Parameter & Concentration $(\mathbf{g} / \mathbf{1 0 0 g})$ \\
\hline Lignin & $5.54 \pm 0.09$ \\
Protein & $5.32 \pm 0.05$ \\
\hline
\end{tabular}

Table 5 indicates the lignin content of the kapok fibre (5.54\%) which disagrees with reported values of $13 \%$ (Kobayashi et al., 1977) and 21.5\% (Hori et al., 2000). The difference in lignin content of the fibre may be due to Kapok sources and processing techniques as reported by Chaiarreki et al (2011). Lignins contribute to compressive strength, water impermeability and resistance to microbial attack of plant tissue (Taiz and Zeiger, 1991; Whettenet al., 1998).

\section{CONCLUSION}

Kapok seed is rich in oil and protein therefore, it has a reasonable economic potential which can be harness through further work in areas like nutritional evaluation and biodiesel production.

\section{REFERENCES}

Akanni, M.S., S.A. Adekunle and E.A. Oluyemi (2005).Physicochemical properties of some nonconventional oil seed. Journal of Food Technology, 3: 177-181.
AOAC (1990). Official Methods of Analysis 15th Edition. Association of Official Analytical Chemist. Washington DC, USA.

Bates, D.M. (2004).Malvales. Encyclopaedia Britannica 2004, CD version

Berry, S.K. (1979). The characteristics of the Kapok (CeibapentadraGaertn.) Seed Oil. Pertanika Journal of Tropical Agricultural Science, 21(1): 1-4

Burris, J.S., (1980). Maintenance of soybean seed quality in storage as influenced by moisture, temperature and genotype. lowa State Journal of Research, 54: 377-389.

Chaiarrekij, S., Apirakchaiskul, A., Suvarnakich, K. and Kiatkamjornwong, S. (2011). Kapok 1: Characteristics of kapok fibre as a potential pulp source for paper making. Bioresources, 7(1): 475488.

Danso, A.A. (2001). State of Forest Genetic.http://www.fao.org/DOCREP/004/AB391E lab391e03.htm\#TopOfpage. Retrieved on 10/11/2004

Mojica, E.R.E.; Merca, F.E., Micor, J.R.L. (2002). Fiber of kapok (Ceiba pentandra) as component of a metal sensor for lead in water samples. Philippine Journal of Crop Science, 27(2): 37-42

Hassan, L.G., Umar, K.J. and Muhammed, A.S (2007). Physicochemical analysis and biofuel properties of silk cotton tree (CeibaPentandra (L.)Gaertn.) seed oil. Biological and Environmental Sciences Journal for the Tropics, 4(2): 71-74.

Hassan, L.G., Sokoto, A.M., Dangoggo, S.M. and Ladan, M.J. (2006). Proximate, amino acids and minerals compositions of silk cotton seeds (Ceibapentandra). African Journal of Natural Sciences, 9: 29-35.

Heuzé, V., Tran, G., (2011). Kapok (Ceibapentandra). Feedipedia.org. A project by INRA,CIRAD,AFZ and FAO. http://www.trc.zootechnie.fr/node/48 Retrieved on September 9, 2011, 11:30.

Hori, K., Flavier, M.E., Kuga, S., Lam, T.B.T. and Liyama, K. (2000). Excellent oil absorbent Kapok (CeibaPentandra CL. Gaertn.) fiber: fiber structure, chemical characteristics and application. Journal Wood Science, 46(5): 401-404.

Kobayashi, Y., Matsuo, R. and Nishiyama, M. (1977). Method for absorption of oils. Japanese Patent, 52: 138, 081.

Louppe, D., Oteng-Amoako, A.A. and Brink, M. (eds.), Plant Resources of Tropical Africa 7: timbers 1. PROTA Foundation, Backhuys Publishers, Leiden, the Netherlands. 
Narahari, D. and AshaRajini, R. (2003). Chemical composition and nutritive value of kapok seed meal for broiler chickens. British Poultry Science, 44(3): 5005-509.

Orwa, C., Mutua, A., Kindt, R., Jamnadass, R. and Anthony, S. (2009). Agroforestree Database: a Tree Reference and Selection Guide Version 4.0. World Agroforestry Centre, Kenya.

Putri, E.M.M., Rachimoellah, M., Santoso, N. and Pradana, F. (2012). biodiesel production from kapok seed oil (Ceiba pentandra) through the transesterification process by using cao as catalyst. Global Journal of Researches in Engineering Chemical Engineering, 12(2): 6-11.

Qiuling, C. and Lin, W. (2009). Structure and property contrast of kapok fibre and cotton fibre. Cotton Textile Technology, 37(11): 668-670.

Kiran, Ch.R., Madhavi, Y. and Rao, T.R. (2012). Evaluation of phytochemicals and antioxidant activities of Ceiba pentandra (Kapok) seed oil.
Journal of Bioanalysis \& Biomedicine, 4(4): 068073. doi:10.4172/1948-593X.1000065

Salgado, A. L. de B.; Ciaramello, D. (1990). Kapok: production from Chorisiaspeciosa. Producao de frutos e de paina de Chorisiaspeciosa St. Hill.BoletimCientificolnstitutoAgronomico $20 \mathrm{pp}$. 27.

Taiz, L. and Zeiger, E. (1991). Plant Physiology. Benjamin/Cummings Publishing Company, Redwood city, USA 559pp.

Tang, A.M, Sun, Z.H., Fu, X., Zi, M., Zhang, H.W., Chen, G. and Lin, Y. (2008). Chemical and Structural Characteristics of Kapok Fibers. Zhonggno Zaozhi Xuebao/Translation of China Pulp and Paper 23(3): 1-5.

Whetten, R.W., Mackey, J.J. and Sederoff, R.R. (1998). Recent advances in understanding lignin biosynthesis. Annual Review of Plant Physiology and Plant Molecular Biology, 49: 585-609. 